\title{
A Study of the Properties of Forming Mixtures Containing Polystyrene Wastes
}

\author{
Olena Dan ${ }^{a^{*}}$, Larysa Trofimovab ${ }^{\mathrm{b}}$ \\ a The John Paul II Catholic University of Lublin, Department of Environmental Engineering, ul. Ofiar Katynia 8b, 37-450 Stalowa Wola, Poland \\ b The State Higher Education Institution "Pryazovskyi State Technical University", Department of Theory of Metallurgical Processes and \\ Foundry Engineering, vul. Universytets'ka 7, Mariupol 87555, Ukraine \\ *e-mail: olena.dan@kul.pl
}

(C) 2021 Authors. This is an open access publication, which can be used, distributed and reproduced in any medium according to the Creative Commons CC-BY 4.0 License requiring that the original work has been properly cited.

Received: 21 March 2021/Accepted: 11 May 2021/ Published online: 9 June 2021

This article is published with open access at AGH University of Science and Technology Press

\begin{abstract}
Expanded polystyrene is widely used as a material for packaging, in modern construction as a heat and sound insulation layer, in thermal insulation systems for buildings, as well as tanks and pipelines. It is additionally used in foundry engineering for the production of models which are gasified during the production of castings from ferrous and non-ferrous alloys under the contact with liquid metal. The use of expanded polystyrene products is associated with waste generation, both in production and in consumption. About $40-50 \mathrm{~kg} /$ person of polystyrene waste is generated per year. The peculiarity of polymeric wastes is their resistance to aggressive environments. They do not rot and the destruction processes in natural conditions proceed rather slowly, with the formation of harmful substances that poison the environment. Therefore, the problem of the processing of waste from polymeric materials is of great importance, not only from the standpoint of environmental protection, but also due to the fact that in conditions of a shortage of polymer raw materials, this waste becomes a powerful raw material resource. This article describes the prospects for recycling expanded polystyrene wastes in foundry engineering. In this work, the properties of molding and core sands containing a combined binder, consisting of a solution of expanded polystyrene wastes in turpentine and clay were investigated, and their main characteristics (weight during stretching and crumbling) were determined. Molding and core mixtures, which contain only a binder in the form of a solution of expanded polystyrene in turpentine, have a crude strength of not more than $0.01 \mathrm{MPa}$. The introduction of a mixture of clay in the amount of 2-3\% allows a crude strength of the mixture of up to $0.05 \mathrm{MPa}$ to be obtained. After drying, the investigated mixtures containing a solution of expanded polystyrene wastes and clay have a tensile strength of up to 2.1 MPa. Mixtures into which a solution of polystyrene wastes and clay was introduced have an insignificant gas capacity and satisfactory gas permeability.
\end{abstract}

\section{Keywords:}

waste, solution, polystyrene, turpentine, strength limit, sprinkling, residual strength

\section{INTRODUCTION}

The use of products made of polymeric materials is inextricably linked with the generation of wastes, both in the field of production and in the field of consumption. The peculiarity of polymer waste is their resistance to aggressive environments. Such materials simply do not rot. The processes of their destruction in natural conditions are quite slow, with the formation of harmful substances that poison the environment. In 2016, the global production of polystyrene and expanded polystyrene (EPS) was around 14.7 and 6.6 million metric tons per annum [1].

The problem of processing and recycling polymeric waste is currently of great importance, not only from the standpoint of environmental protection but also due to the fact that in conditions of shortage of polymeric raw materials, such wastes become a powerful raw material resource.

The properties of sand-clay molding mixtures containing a solution of polystyrene waste in turpentine as a component are the object of the study. The aim of this study is to improve the properties of sand-clay molding and core mixtures by using a solution of EPS in turpentine as a binder.

\section{USE OF EXPANDED POLYSTYRENE AND THE FORMATION OF ITS WASTE}

EPS can be found in many areas of modern life. EPS is widely used as a material for food packaging and storage. This fact emphasizes the hygienic properties of EPS, the properties of which do not change over time. EPS packaging often contains 
meat, fish, frozen or fresh vegetables, and beverages. Almost all packaging for household electronics is currently made of EPS. It is widely used in modern construction as a heat and sound insulation layer in systems of warming of houses and other buildings, and also capacitive devices and pipelines [2-5]. EPS is also used in foundry engineering to obtain models under gasification in contact with liquid metal in the production of castings from ferrous and nonferrous alloys [6-10]. Up to $10 \%$ of raw materials goes to waste during the production of gasified models by the method of thermoplotter cutting of polystyrene block [11].

\section{RE-USING OF EPS WASTE}

EPS packaging accounts for $40 \%$ of all household waste and does not decompose. Therefore, the use of such packaging is associated with the generation of waste totaling approximately 40-50 kg/year per person [11]. EPS wastes do not decompose during deposition in landfills and cause great damage to the soil. An alternative method is incineration. However, compounds are released during combustion which cause acid rain and is detrimental to the environment. Ash is also formed during combustion which is easily sprayed with air over a large area. Such ash causes great harm when inhaled, leading to pulmonary poisoning and irritation.

Generally, re-using, mechanical recycling, chemical recycling, and energy recovery have been the four main options conventionally-used for the reclamation and recycling of plastics. EPS contains more than $98 \%$ of air, making its recycling uneconomical and inexpedient [12].

These are the following priority areas for the re-use of EPS waste [13-17]:

- polystyrene coating for waterproofing,

- protective and decorative polystyrene coverings,

- polystyrene coatings for pottery,

- paints and varnishes for painting,

- thermocompaction of polystyrene waste,

- composite materials with expanded polystyrene matrix,

- binder component for molding and rod mixtures.

It should be noted that molding and rod mixtures based on the binder have easy knockout and high strength [18-23]. EPS wastes are mainly used in foundry engineering as a component for molding and core mixtures in the form of solutions at the metallurgical enterprises of Ukraine and nearby countries.

The preparation of solutions of EPS in organic solvents is due to a multiple decrease in the initial volume of expanded polystyrene and a significant increase in the volume of the solution compared to the volume of the solvent. Therefore, the preparation of polystyrene solutions is a convenient way to compact it. The most commonly used solvent for polystyrene wastes is gum turpentine [24]. Turpentine dissolves polystyrene wastes well and has low volatility.

As a result of a number of studies [20-23], the technology of EPS recycling was created. It is possible to make modern, low-toxic binding materials for the production of sand molding and core mixes, and also coverings of molds using
EPS wastes. It makes it possible to improve and develop new, more efficient and cost-effective metal casting processes. In addition, the use of EPS wastes is of great environmental importance, as it is about reducing the amount of such wastes in landfills [25-29].

If the low volatility of gum turpentine is a positive factor from the point of view of the requirements of sanitary working conditions, it is negative from the perspective that there is a technological need to ensure the accelerated hardening of forms and cores, since this demands the compulsory removal of any solvent from mix. There are a number of ways to remove the liquid composition from the mixture, including vacuuming and blowing the mixture with dry heated air. The temperature exposure during drying in ovens is the most affordable method [26-28]. Analyzing the use of an EPS solution as a binder for molding and core mixtures, a number of problems can be identified that are associated with the implementation of this scheme into production.

The most significant problem is technical. The use of binder in a "pure" form provides a raw strength of mixtures of no more than $0.01 \mathrm{MPa}$. It is known that if the strength of mixtures in the raw state is very low - less than $0.01 \mathrm{MPa}$, it requires the use of additional special equipment-drivers, equipment necessary to move the manufactured product to the driver, subsequent transportation and heat treatment to obtain the required technological strength, which increases the cost of production as well as lengthening the technological cycle of manufacturing casting. The solution to this problem may be the application of a combined binder containing additional liquid glass or clay to the EPS solution [27-30].

\section{MATERIALS AND METHODS}

In this study, research was carried out by dissolving EPS waste PSBS-25 in turpentine (Technical Specification No. 24.3-30959 201-001-2004). The choice of PSBS-25 samples is justified by the fact that it is used in the manufacture of models for Lost Foam technology by means of thermoplotter cutting. PSPB-25 is the most common type of expanded polystyrene due to its low density, and therefore a low ash residue after combustion and low carburization of steel. 30\% of the used polystyrene foam is scraped off. Therefore, disposal of polystyrene foam wastes is an urgent problem. Dissolving them with turpentine is a regulated and environmentally friendly process. Turpentine vapors are environmentally neutral, unlike nitro solvents.

The quartz sand grade K2 was used as a grain base for the preparation of mixtures. A clay from deposit of Chasiv Yar was used as a binder in the form of a dry powder.

The mixture was prepared in a paddle mixer. First, the dry components were mixed for 5 minutes, and then a solution of foam plastic in turpentine was added and mixed for 10 minutes.

Standard test samples were made using the 2M030 laboratory device for the production of standard samples of foundry mixture. Drying of the samples was performed in a chamber dryer model for 1 hour at a temperature of $150^{\circ} \mathrm{C}$.

Compression and tensile tests were performed on standard samples on a universal model device 5070A. Determination 
of gas permeability was carried out using the accelerated method DSTU 29234.11-91 by passing room temperature air through a standard sample of the test material on the model device $042-\mathrm{M}$. The gas-forming capacity of the mixture was determined in accordance with GOST 23409.12-78

- "Molding and rod mixtures. Method for determining gas solubility".

Scattering was determined on standard samples according to DSTU 23409.9-78: in 10 minutes after preparation of mixtures and production of samples, in an hour, in 3 hours and after 24 hours. Residual strength was determined by heat shock in the temperature range $150-800^{\circ} \mathrm{C}$.

The hygroscopicity of the samples was determined according to GOST 23409.10-78.

\section{RESULTS AND DISCUSSION}

\subsection{Dissolution of EPS in turpentine}

It is known from the literature [17-20] that the best strength properties of foundry mixtures are given by $38-40 \%$ solution of EPS in turpentine.

Preparation of such a solution from EPS waste in turpentine showed the first positive result of the study on their utilization, namely that there is a sharp decrease in the volume of waste.

Figure 1 shows the volume of 40 grams of EPS waste and the volume of the solution obtained after dissolution to obtain the desired $40 \%$ concentration (ingredients ratio EPS $/$ turpentine $=40 \mathrm{~g} / 60 \mathrm{~g}$ ). a)

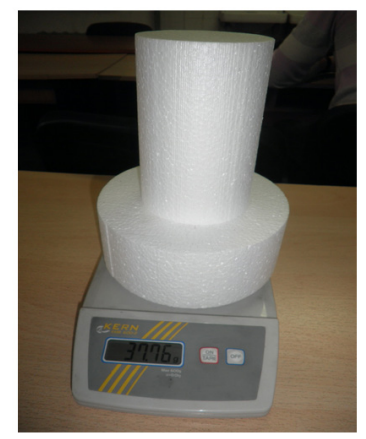

b)

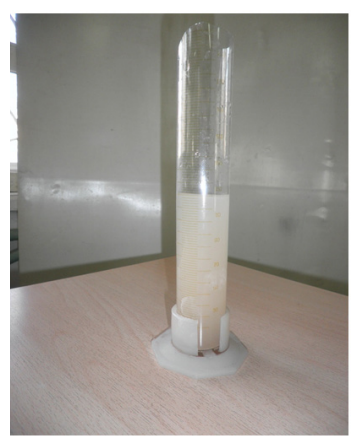

Fig. 1. The volume of 40 grams of EPS waste: a) before dissolution; b) after dissolution

\subsection{Investigation of the properties of molding mixtures containing EPS wastes and clay as a binder}

In this study, the possibility was investigated of obtaining molding of a sufficient raw strength by introducing small additives of molding clay mixtures with a binder solution of EPS waste in turpentine.

In the preparation of mixtures, $1.5,2.0$ and $3.0 \%$ clay was administered. Figure 2 shows the effect of clay content on the raw compressive strength, and Figure 3 on the dry tensile strength of mixtures.

From the figures it is visible that the introduction of clay in the investigated mix allows us to obtain a crude durability of more than $0,01 \mathrm{MPa}$. So, the possibility of manipulation of cores without additional technological operations and special equipment is provided. Increasing the clay content from $1.5 \%$ to $3.0 \%$ leads to an increase in the raw compressive strength of the samples from $0.01 \mathrm{MPa}$ to $0.05 \mathrm{MPa}$. At the same time, the tensile strength of dry samples increases insignificantly from 2.07 MPa to 2.10 MPa.

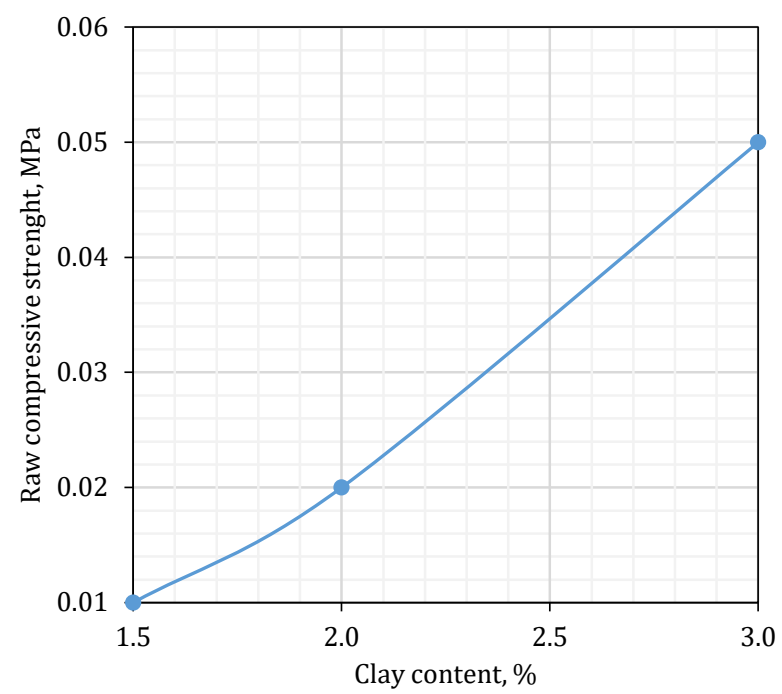

Fig. 2. Influence of clay content on crude compressive strength of mixtures

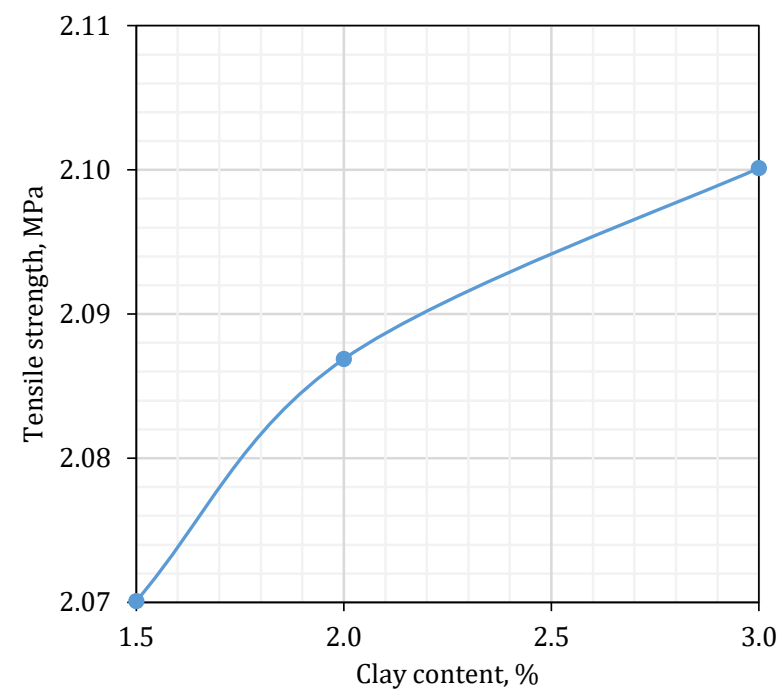

Fig. 3. Influence of clay content on the dry tensile strength of the mixture

Measurement of the gas capacity of the studied mixtures of $2 \%$ clay showed their insignificant gas evolution $\left(10 \mathrm{~cm}^{3} / \mathrm{g}\right)$, and gas permeability (275 units). The hygroscopicity of these mixtures was $0.14 \%$, which makes it possible after storage to keep the rods and molds for a long time without compromising their properties.

The obtained results were compared with the available literature data [20] on the strength of the mixture with different compositions. It was found that the strength of the mixture with an EPS waste binder is at the level of existing analogues with resins, and exceeds them in terms of manufacturability and harmful effects on the environment. 
Residual strength was determined on samples of a mixture containing $3 \%$ clay, after heating to $150,200,250,300$ and $400^{\circ} \mathrm{C}$. The test results of the samples under compression are shown in Figure 4.

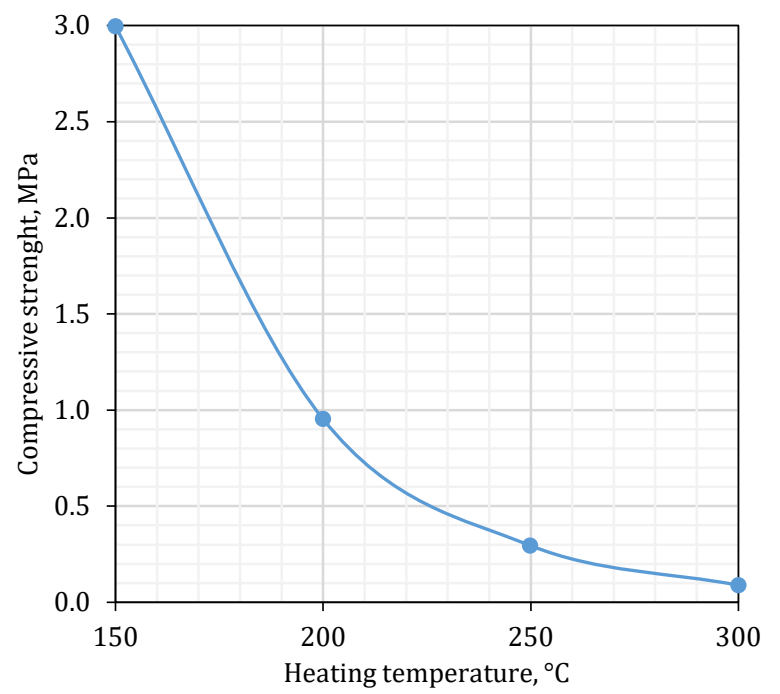

Fig. 4. Residual strength of samples after heating

The compressive strength of this mixture after exposure to $150^{\circ} \mathrm{C}$ for 1 hour exceeds $3 \mathrm{MPa}$.

The curve in Figure 4 shows that the investigated mixture begins to lose strength intensively at $250^{\circ} \mathrm{C}(\sigma=0.3 \mathrm{MPa})$. Presumably this is due to the thermal destruction of the polystyrene film that binds the grains of sand. After heating to $300^{\circ} \mathrm{C}$, the mixture significantly loses strength $(\sigma=0.08 \mathrm{MPa})$, and after heating to $400^{\circ} \mathrm{C}$, the samples were destroyed in the furnace.

\subsection{Investigation of the effect of small impurities of EPS solution in turpentine on the properties of standard sand-clay mixtures}

The study was performed on a sand-clay mixture containing $10 \%$ clay as a binder. Additionally, a $40 \%$ solution of EPS in turpentine was introduced into the mixture (this corresponded to $0.4 \%$ in terms of polystyrene). Samples of the control mixture that did not contain polystyrene were examined at the same time. The bulkiness and residual strength (which characterizes the knockout) of mixtures were investigated.

The bulk (surface strength) characterizes the ability of a mold or rod to maintain its configuration under the influence of a jet of liquid metal, as well as other forces that occur, for example, during transportation or assembly of the mold. One way to reduce the scattering is to increase the clay content in the mixture. The inevitable consequence of increasing the clay content in the mixture is a deterioration of its knockout and pliability, which is undesirable.

The aim of this stage of the study was to use small impurities of a solution of expanded polystyrene in turpentine to obtain a sand-clay mixture with high scattering rates and low residual strength.
Figure 5 in semi-logarithmic coordinates shows a graph of the change in the scattering of the control and experimental mixture over time. During the experiments, it was observed that the samples from the test mixture had a scatter less than the control in all cases.

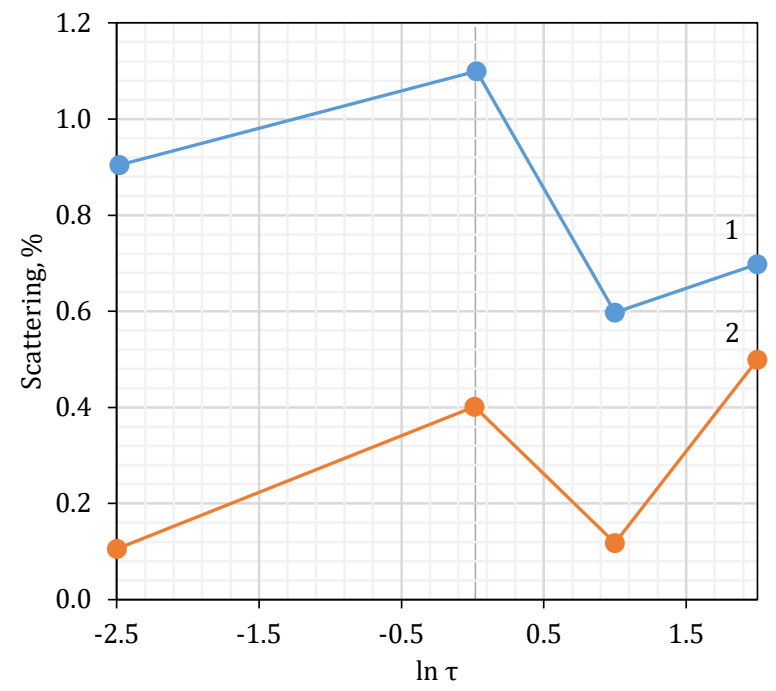

Fig. 5. Changes in the scattering of the control (1) and experimental (2) mixture over time $\tau$

The figure shows that after exposure for 1 hour, the scattering of both mixtures increases slightly, after 3 hours decreases significantly and, after 24 hours, grows again.

Figure 6 shows the dependence of the residual strength of the test mixture in comparison with the control from the heating temperature of the samples.

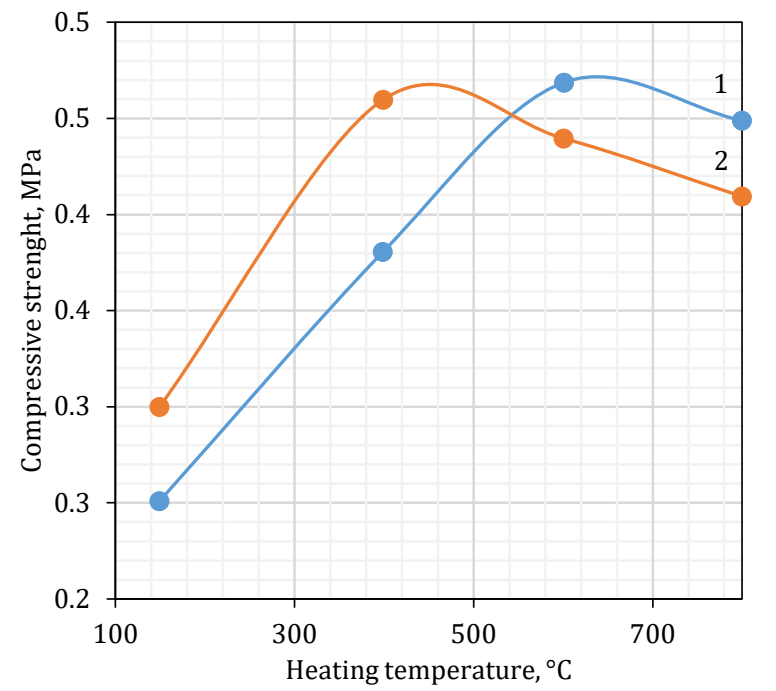

Fig. 6. Residual strength of samples from the control (1) and experimental (2) mixtures

Figure 6 shows that the mixture has greater tensile strength than the control in the initial state of the test. That is, the admixture of expanded polystyrene solution acts as a strengthening component.

It was found that at heating temperatures $<600^{\circ} \mathrm{C}$, the test specimens also had a residual strength greater by $15-20 \%$ 
than the control ones. This is most likely due to the incomplete destruction of the polystyrene molecules. The completion of this process at a higher temperatures $\left(600-800^{\circ} \mathrm{C}\right)$ provided a decrease in the compressive strength of the experimental samples in comparison with the control by 10-12\% (Fig. 6), so the mixture of these samples had better knockout. Analysis of Figure 6 shows that a small amount of EPS waste acts as a strengthening and softening component of the sand-clay mixture.

\section{CONCLUSIONS}

A large amount of waste is generated under the production and consumption of expanded polystyrene. Possessing chemical inertness, this waste accumulates in the environment and harms it. Expanded polystyrene wastes can be used as a raw material for the production of waterproofing, protective and decorative coatings for wood and pottery, paints and varnishes for painting, the basis of composite materials, a binder component for molding and core mixtures in foundry production.

Based on the research, it was found that:

1. Molding and core mixtures containing only a binder in the form of an EPS solution in turpentine, have a raw strength of not more than $0.01 \mathrm{MPa}$.

2. The introduction of clay into the mixture in the amount of 2.0-3.0\% allows us to obtain a crude strength of the mixture of up to $0.05 \mathrm{MPa}$.

3. After drying, the test mixtures, in which a solution of EPS waste and clay was introduced, have a tensile strength from 2.07 MPa to 2.10 MPa.

4. Mixtures with the EPS waste solution and clay have insignificant gas capacity and satisfactory gas permeability.

5. The study of the effect of small impurities of the EPS solution in turpentine on the properties of sand-clay mixtures have revealed that the studied mixtures (in comparison with the control) have less scattering and residual strength.

\section{REFERENCES}

[1] Uttaravalli A.N., Dinda S. \& Gidla B.R. (2020). Scientific and Engineering Aspects of Recycling and Reuse of Expanded Polystyrene Waste for Various Potential Applications: A Review. Process Safety and Environmental Protection, 137, 140-148. Doi: https://doi.org.10.1016/j.psep.2020.02.023.

[2] Ramli Sulong N.H., Mustapa S.A.S. \& Abdul Rashid M.K. (2019). Application of expanded polystyrene (EPS) in buildings and constructions: A review. Journal of Applied Polymer Science, 136, 47529. Doi: https://doi.org.10.1002/app.47529.

[3] Khlyestova O.A. \& Dubovkina M.Yu. (2016). Enerhoefektyvnist vykorystannya teploizolyatsiynykh materialiv dlya uteplennya zhytlovykh budynkiv. Marketynhovi komunikatsiyi ta lohistyka u sferi tekhnolohiy enerhozberezhennya v Ukrayini ta sviti: Mizhnar. naukovo-prakt. konf.: 9.11.2016. Dnipro, Dnipro: Dnipropetrov. nats. un-t im. 0. Honchara, 20-23 [Хлєстова 0.A., Дубовкіна М.Ю. (2016). Енергоефективність використання теплоізоляційних матеріалів для утеплення житлових будинків. Маркетингові комунікації та логістика у сфері технологій енергозбереження в Україні та світі: Міжнар. науково-практ. конф:: 9.11.2016. Дніпро Дніпро: Дніпропетров. нац. ун-т ім. О. Гончара, 20-23].
[4] Savkin Yu.V. (2012). Rossiyskiy rynok penopolistirola: zadachi, dostizheniya, perspektivy. Stroitel'nyye materialy, 1, 1-3 [Савкин Ю.В. (2012). Российский рынок пенополистирола: задачи, достижения, перспективы. Строительные материалы, 1, 1-3].

[5] Shulyak V.S., Rybakov S.A. \& Grigoryan K.A. (2001). Proizvodstvo otlivok po gazifitsiruyemym modelyam. Moskva: MGIU [Шуляк В.С., Рыбаков С.А., Григорян К.А. (2001). Производство отливок по газифицируемым моделям. Москва: МГИУ].

[6] Ozerov V.A., Shulyak V.S. \& Plotnikov G.A. (1970). Lit'ye po modelyam iz penopolistirola. Moskva: Mashinostroyeniye [Озеров В.А., Шуляк В.С., Плотников Г.А. (1970). Литье по моделям из пенополистирола. Москва: Машиностроение].

[7] Stepanov Yu.A. \& Grishin D.S. (1976). Lit'ye po gazifitsiruyemym modelyam. Moscow: Mashinostroenie [Степанов Ю.А., Гришин Д.С. (1976). Литье по газифицируемым моделям. Москва: Машиностроение].

[8] Chudnovskiy A.R. (1970). Lit'ye po modelyam iz penoplasta. Moskva: Khimiya [Чудновский А.Р. (1970). Литье по моделям из пенопласта. Москва: Химия].

[9] Kirpichenkov V.P. (1971). Tekhnologicheskiy protsess lit'ya po gazifitsiruyemym modelyam. Moskva: NIIMASH [Кирпиченков В.П. (1971). Технологический процесс литья по газифицируемым моделям. Москва: НИИМАШ].

[10] Dan L.A., Trofimova L.A.\& Velichko A.A. (2009). Analiz vozmozhnosti primeneniya termoplottera dlya izgotovleniya gazifitsiruyemykh liteynykh modeley. Vestnik Priazovskogo Gosudarstvennogo Tekhnicheskogo Universiteta, 19, 84-86 [Дан Л.А., Трофимова Л.А., Величко А.А. (2009). Анализ возможности применения термоплоттера для изготовления газифицируемых литейных моделей. Вестник Приазовского Государственного Технического Университета, 19, 84-86].

[11] Penopolistirol i yestestvennaya sreda. Fakty [Пенополистирол и естественная среда. Факты]. Retrieved from http://stroika. biz.ua/articles/350/ [3.05.2021].

[12] Rajaeifar M.A., Abdi R. \& Tabatabaei M. (2017). Expanded polystyrene waste application for improving biodiesel environmental performance parameters from life cycle assessment point of view. Renewable and Sustainable Energy Reviews, 74, 278-298. Doi: https://doi.org.10.1016/j.rser.2017.02.032.

[13] Ponomareva V.T., Likhacheva N.N. \& Tkachik Z.A. (2002). Ispol'zovaniye plastmassovykh otkhodov za rubezhom. Plasticheskiye massy, 5, 44-48 [Пономарева В.Т., Лихачева Н.Н., Ткачик 3.А. (2002). Использование пластмассовых отходов за рубежом. Пластические массы, 5, 44-48].

[14] Shtarke L. (1987). Ispol'zovaniye promyshlennykh ibytovykh otkhodov plastmass. Leningrad: Khimiya [Штарке Л. (1987). Использование промышленных и бытовых отходов пластмасс. Ленинград: Химия].

[15] Pirs D. \& Uolter I. (1981). Ispol'zovaniye vtorichnykh resursov: ekonomicheskiye aspekty. Moskva: Ekonomika [Пирс Д., Уолтер И. (1981). Использование вторичных ресурсов: экономические аспекты. Москва: Экономика].

[16] Hocking M.B. (1991). Paper Versus Polystyrene: A Complex Choice. Science. 251, 504-505. Doi: https://doi.org.10.1126. science.251.4993.504.

[17] Dan L.A., Oleynik I.M. \& Trofimova L.A. (2013). Svoystva zashchitnykh pokrytiy na osnove otkhodov penopolistirola. Vestnik Priazovskogo Gosudarstvennogo Tekhnicheskogo Universiteta, 27, 110-115 [Дан Л.А., Олейник И.М., Трофимова Л.А. (2013). Свойства защитных покрытий на основе отходов пенополистирола. Вестник Приазовского Государственного Технического Университета, 27, 110-115].

[18] Doroshenko V.S. (2014). Novyye napravleniya pererabotki otkhodov penopolistirola. Ekologiya predpriyatiya, 1, 68-78 [Дорошенко В.С. (2014). Новые направления переработки отходов пенополистирола. Экология предприятия, 1, 68-78].

[19] Shinskiy O.I., Doroshenko V.S. \& Stryuchenko A.A. (2008). Polucheniye svyazuyushchikh materialov dlya formovochnykh i sterzhnevykh peschanykh smesey iz otkhodov penopolistirola. Metall i lit'ye Ukrainy, 3-4, 57-61 [Шинский О.И., Дорошенко B.С., Стрюченко А.А. (2008). Получение связующих материалов для формовочных и стержневых песчаных смесей из отходов пенополистирола. Металл и литье Украины, 3-4, 57-61]. 
[20] Shinskiy O.I., Ladareva Yu.Yu. \& Mairko T.A. (2007). Novyy svyazuyushchiy material na osnove otkhodov penopolistirola. Protsessy lit'ya, 4, 58-60 [Шинский О.И., Ладарева Ю.Ю., Маирко Т.А. (2007). Новый связующий материал на основе отходов пенополистирола. Процессы литья, 4, 58-60].

[21] Stryuchenko A.A., Ladareva Yu.Yu. \& Mairko T.A. (2005). Novyye metody utilizatsii bytovykh i promyshlennykh otkhodov penopolistirola. Tezisy dokladov mezhdunarodnogo nauchno-tekhnicheskogo kongressa: Ekonomicheskiy put' k vysokokachestvennomu lityu: 2005. Kiyev [Стрюченко А.А., Ладарева Ю.., Маирко А.А. (2005). Новые методы утилизации бытовых и промышленных отходов пенополистирола. Тезисы докладов международного научно-технического конгресса: Экономический путь к высококачественному литью: 2005. Киев].

[22] Stryuchenko A.A., Ladareva Yu.Yu. \& Mairko T.A. (2005). Formovochnyye i sterzhnevyye smesi na polistirol'nom svyazuyushchem. Tezisy dokladov mezhdunarodnogo nauchno-tekhnicheskogo kongressa: Ekonomicheskiy put' k vysokokachestvennomulit'yu: 2005. Kiyev [Стрюченко А.А., Ладарева Ю.Ю., Маирко А.А. (2005). Формовочные и стержневые смеси на полистирольном связующем. Тезисы докладов международного научно-технического конгресса: Экономический путь к высококачественному литью: 2005. Киев].

[23] Shinskiy O.I., Stryuchenko A.A. \& Doroshenko V.S. (2009). Polucheniye svyazuyushchikh iz otkhodov penopolistirola dlya liteynykh form i strezhney i izucheniye ryada kharakteristik etikh protsessov. Protsessy lit'ya, 1, 48-52 [Шинский О.И., Стрюченко А.А. Дорошенко В.С. (2009). Получение связующих из отходов пенополистирола для литейных форм и стрежней и изучение ряда характеристик этих процессов. Процессы литья, 1 , 48-52].

[24] Shinsky O.I., Terlikovsky E.V. \& Stryuchenko A.A. (2005). UA Patent No. 9003. Kyiv, Ukrainian Patent Office.

[25] Dan L.O., Trofimova L.A., Shevchenko S.V., Shvarts V.L \& Dan O.L. (2013). UA Patent No. 102624. Kyiv, Ukrainian Patent Office.
[26] Dan L.A., Trofimova L.A., Reva I.A. \& Dan Ye.L. (2014). Svoystva smesey so svyazuyushchim, soderzhashchim otkhody penopolistirola i glinu. Liteynoye proizvodstvo, 4, 24-26 [Дан Л.А., Трофимова Л.А., Рева И.А., Дан Е.Л. (2014). Свойства смесей со связующим, содержащим отходы пенополистирола и глину. Литейное производство, 4, 24 -26].

[27] Dan L.A. \& Trofimova L.A. (2014). Osypayemost' i vybivayemost' peschano-glinistykh smesey soderzhashchikh malyye dobavki rastvora penopolistirola. Universitetskaya nauka - 2014: Mezhdunarodnaya nauchno-tekhn. konf.: 20-22 maya. Mariupol'. Mariupol': PGTU, 130-131 [Дан Л.А., Трофимова Л.А. (2014). Осыпаемость и выбиваемость песчано-глинистых смесей содержащих малые добавки раствора пенополистирола. Университетская наука - 2014: Международная научно-техн. конф:: 20-22 мая. Мариуполь. (сс. 130-131). Мариуполь: ПГТУ].

[28] Dan L.A. \& Trofimova L.A. (2014). Vliyanie malyh dobavok rastvora penopolistirola v skipidare na osypaemost' i vybivaemost' peschano-glinistyh smesej. Novi materiali i tekhnologiï v mashinobuduvanni: materiali VI Mizhnar. naukovo-tekhnich. konf.: May 20 - May 21. Kyiv. (pp. 32-33). Kyiv: National Technical University of Ukraine "Igor Sikorsky Kyiv Polytechnic Institute" [Дан Л.А., Трофимова Л.А. (2014). Влияние малых добавок раствора пенополистирола в скипидаре на осыпаемость и выбиваемость песчано-глинистых смесей. Нові матеріали і технології в машинобудуванні: матеріали VI Міжнар. науково-техніч. конф.: 20 - 21 мая. Киев. (сс. 32-33). Киев: НТУ КПI].

[29] Shinskiy O.I., Ladareva Yu.Yu. \& Rybitskiy A.I. (2010). Razrabotka svyazuyushchego materiala dlya liteynogo proizvodstva putem pererabotki otkhodov penopolistirola. Protsessy lit'ya, 4, 56-59 [Шинский О.И., Ладарева Ю.Ю., Рыбицкий А.И. (2010). Разработка связующего материала для литейного производства путем переработки отходов пенополистирола. Процессы литья, 4, 56-59].

[30] Ponomarenko O., Yevtushenko N. \& Lysenko T. (2019). A New Technology for Producing the Polystyrene Foam Molds Including Implants at Foundry Industry. Advances in Design, Simulation and Manufacturing, II, 430-437. Doi:10.1007/978-3-030-22365-6_43. 